\title{
PENGEMBANGAN INDEKS BAHAYA KEBAKARAN DI HTI SBAWI SUMATRA SELATAN
}

\author{
Development of Fire Danger Index at SBA Wood Industries, \\ South Sumatra \\ Muh. Taufik ${ }^{1}$, B.I. Setiawan ${ }^{2}$, L.B. Prasetyo ${ }^{3}$, N.H. Pandjaitan ${ }^{2}$, \\ dan/and Soewarso ${ }^{4}$ \\ ${ }^{1}$ Departemen Geofisika dan Meteorologi, FMIPA IPB. \\ Jl. Meranti Wing 19 lv. 4 Kampus IPB Darmaga, Bogor, email: mtaufik@ipb.ac.id \\ ${ }^{2}$ Departemen Teknik Sipil dan Lingkungan, FATETA - IPB, Kampus IPB Darmaga \\ ${ }^{3}$ Dep. Konservasi Sumberdaya Hutan dan Ekowisata, FAHUTAN - IPB, Kampus IPB Darmaga \\ ${ }^{4}$ SBA Wood Industries, Sinarmas Forestry, Palembang.
}

Naskah masuk : 7 Oktober 2010; Naskah diterima : 1 Agustus 2011

\begin{abstract}
Fire danger rating system is one of importance for detecting fire danger potential situated in forest estate. Keetch-Byram Drought Index (KBDI) is an index for assessing early fire danger as it only requires daily rainfall and maximum air temperature data. This paper will discuss application of KBDI for the early detection of fire danger in SBA Wood Industries. The study site was located in Ogan Komering Ilir District, South Sumatera in which improvement of KBDI parameters is needed to satisfy local climate and hydrology conditions. Using data observation from 1 April 2009 to 11 May 2010 from HQ Baung station including daily rainfall, maximum air temperature, and water table depth, KBDI for wetland ecosystem was developed. Through the optimization process, we obtained the values of parameters for calculating KBDI that met local condition. In its application, KBDI had a good performance in detecting a fire danger potential that is in the extreme levels of fire danger there were six fire occurrences in around station. We found a critical depth of water table that able to maintain KBDI in safer level for fire is in depth of $0.659 \mathrm{~m}$. The deeper of water table depth, the more fire risks would be.
\end{abstract}

Keywords: KBDI, optimization, water table depth, wetland, South Sumatera

\begin{abstract}
ABSTRAK
Sistem peringkat bahaya kebakaran sangat penting pada kondisi pengelolaan hutan tanaman industri untuk mendeteksi potensi kebakaran. Keetch-Byram Drought Index (KBDI) merupakan satuan indeks kebakaran yang dapat digunakan untuk menilai bahaya kebakaran hutan secara dini karena hanya memerlukan data curah hujan dan suhu udara maksimum harian saja. Makalah ini akan mengurai penggunaan KBDI untuk deteksi dini bahaya kebakaran hutan di SBA Wood Industries. Penelitian dilakukan di Ogan Komering Ilir, Sumatera Selatan dengan melakukan perbaikan terhadap nilai parameter KBDI agar sesuai dengan kondisi setempat. Metode yang digunakan adalah: (i) pengamatan terhadap curah hujan, suhu udara, dan kedalaman muka air tanah untuk periode 1 April 2009 sampai 11 Mei 2010 digunakan untuk penghitungan model KBDI pada lahan basah, (ii) proses optimisasi untuk memperoleh nilai parameter baru dalam perhitungan faktor kekeringan dan faktor muka air tanah. KBDI yang dikembangkan memiliki kinerja yang baik dalam mendeteksi bahaya kebakaran hutan yaitu kejadian kebakaran hanya terjadi pada level ekstrim. Hasil penelitian menunjukkan bahwa kedalaman muka air tanah kritis untuk mempertahankan KBDI pada level yang aman yaitu pada kedalaman 0,659 m, dan jika kedalaman melebihi nilai kritis tersebut maka potensi bahaya kebakaran di lokasi SBAWI akan meningkat.
\end{abstract}

Kata kunci : KBDI, optimisasi, kedalaman muka air, lahan basah, Sumatera Selatan 


\section{PENDAHULUAN}

Kebakaran hutan telah menyebabkan degradasi ekologi yang serius seperti kerusakan pada habitat alam (Ager et al., 2007), perubahan komposisi dan struktur ekosistem hutan (Senkowsky, 2001; Johnstone dan Chapin III, 2006; Wallenius et al., 2007; Chuvieco et al., 2009), dan dampak yang lebih serius adalah gangguan terhadap kesehatan masyarakat. Di Indonesia, kebakaran hutan biasanya terjadi pada saat musim kemarau panjang dan kegiatan pembukaan lahan yang masih mengunakan api. Kedua kondisi tersebut akan menimbulkan kondisi ekstrim berupa akumulasi biomassa kering yang mudah terbakar terutama jika terjadi pada lahan bergambut.

Kajian ilmiah kebakaran hutan sangat penting dan banyak dilakukan mengingat dampaknya yang nyata terhadap lingkungan dan kehidupan manusia (van der Werf et al., 2008; Page et al., 2002; Gill \& Stephens, 2009). Penelitian untuk mendapatkan indeks bahaya kebakaran sebagai bagian penting dalam sistem deteksi dini kebakaran telah dilakukan oleh Burgan (1988), Keetch \& Byram (1968), Wybo et al. (1995) dan Snyder et al. (2006).

Indeks bahaya kebakaran yang dinamis dibangun berdasarkan variabel meteorologi dan kondisi aktual vegetasi (Snyder et al., 2006), yaitu kondisi kelembaban tanah dan struktur vegetasi yang mudah terbakar dan kondusif bagi penyebaran api. Indeks bahaya kebakaran yang dinamis memerlukan dukungan data meteorologi seperti curah hujan, suhu udara, kelembaban udara dan kecepatan angin, serta kondisi kesegaran vegetasi atau biomassa seperti yang digunakan untuk membangun Fire Weather Index (Stocks et al., 1989; Wybo et al., 1995). Selain indeks tersebut, terdapat juga indeks yang dikembangkan oleh Keetch \& Byram (1968) yaitu Keetch-Byram Drought Index. Indeks tersebut memformulasikan perubahan kelembaban tanah sebagai pengaruh dari dua variabel iklim saja, yaitu hujan dan suhu maksimum harian.

Awalnya KBDI diformulasikan untuk wilayah sub-tropika lahan kering (antara lain: Alexander, 1990; Burgan, R.E., 1988) tetapi dalam perkembangannya diterapkan juga di wilayah tropika (Buchholz dan Weidemann, 2000; Chan, et al., 2004). Lebih jauh lagi, Murdiyarso et al. (2002) dan Weidemann et al. (1998) juga telah menerapkan KBDI di beberapa lahan basah bergambut di Indonesia dengan menggunakan paremeter KBDI awal (Keetch \& Byram 1968). Penggunaan parameter awal ini cenderung mengabaikan jenis tanah, tipe iklim dan hidrologi (Chan et al., 2004; Cooke et al., 2007; Sparks et al., 2002; Reardon et al., 2009), yang oleh Liu et al. (2010) diamati akan menghasilkan perbedaan pada tingkat kehilangan uap air dari tanah. Dalam kaitan ini dan mengingat keberadaan muka air tanah lebih dekat ke permukaan tanah, Setiawan et.al. (2009) memodifikasi formulasi KBDI dan memperoleh parameter KBDI baru melalui proses optimisasi merujuk pada data kelembaban air tanah.

Penelitian ini bertujuan mengkaji kinerja pengembangan KBDI yang dimodifikasi di HTI SBAWI Sumatera Selatan, dan untuk mendapatkan nilai parameter KBDI yang sesuai dengan kondisi lokal.

\section{BAHAN DAN METODE}

\section{A. Waktu dan Tempat}

Penelitian ini dilakukan di HTI SBAWI yang berlokasi di Kabupaten Ogan Komering Ilir, Sumatera Selatan pada periode 1 April 2009 - 11 Mei 2010. Titik lokasi pengamatan lapangan ditentukan dengan membangun stasiun cuaca otomatis (automatic weather station) di Head Quarter Baung (Gambar 1). Tipe tanah di lokasi penelitian tergolong marine clay dengan kadar air tanah jenuh sebesar $0,634 \mathrm{~m}^{3} / \mathrm{m}^{3}$ dan kadar air pada titik layu permanen sebesar $0,320 \mathrm{~m}^{3} / \mathrm{m}^{3}$.

\section{B. Bahan dan Alat}

Data cuaca dan hidrologi diamati secara otomatis tiap jam untuk periode pengamatan 1 April 2009 - 11 Mei 2010. Curah hujan diukur dengan tipping bucket tipe Decagon Em50. Data hujan pengamatan diakumulasikan selama 24 jam untuk mendapatkan data hujan harian. Data suhu udara diukur dengan sensor HIOKI 3641 untuk mendapatkan data suhu udara maksimum harian. Kadar air tanah diukur dengan Decagon Em50 dengan 2 sensor yang ditanam pada kedalaman 0-10 $\mathrm{cm}$. Data kadar air tanah merupakan rata-rata dari dua pengamatan tersebut. Kedalaman muka air tanah diukur secara otomatis dengan TD Diver. Pengamatan kedalaman muka air tanah dilakukan tiap jam. 


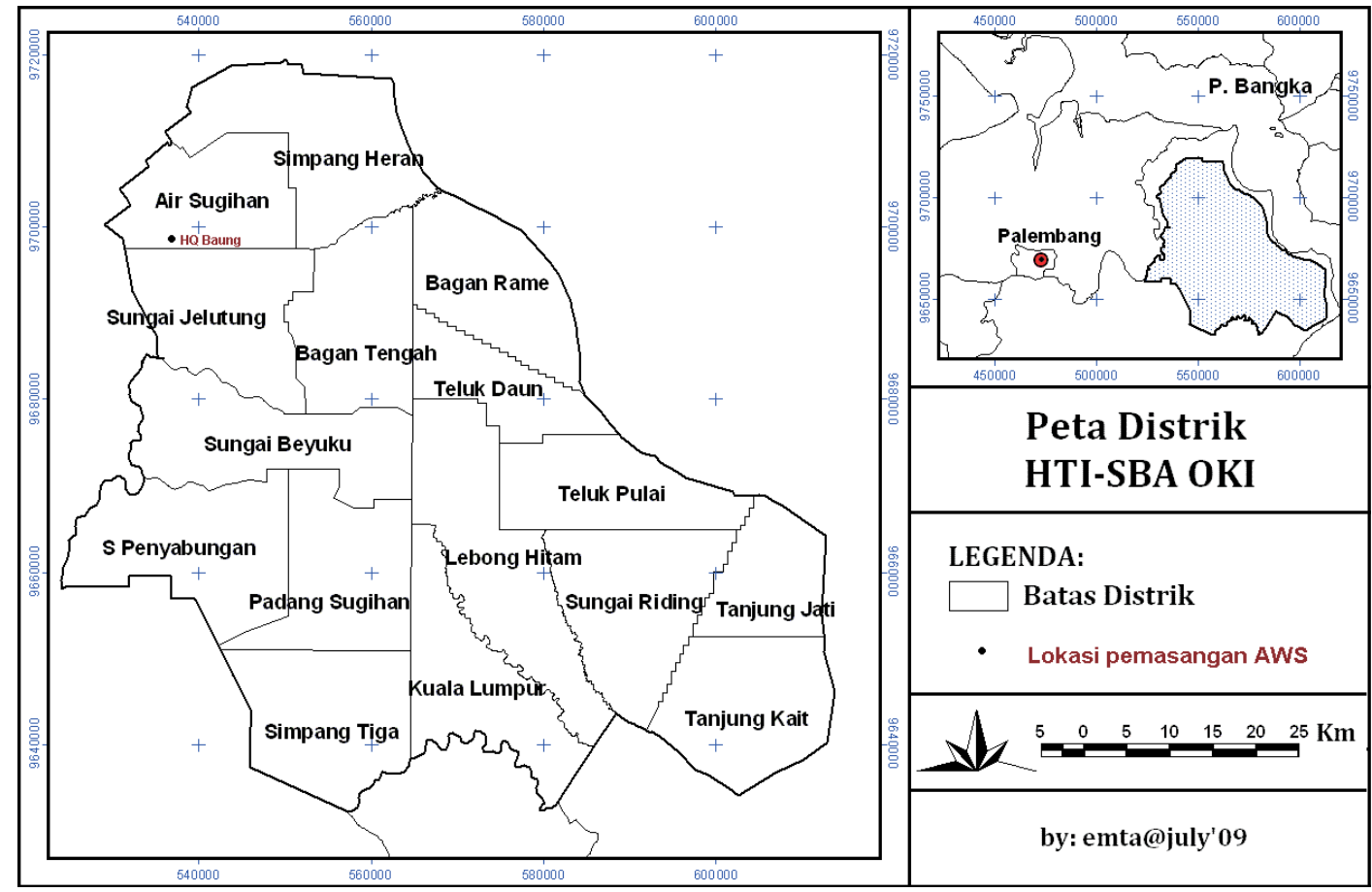

Gambar(Figure) 1. Lokasi HTI SBAWI di Ogan Komering Ilir - Sumatra Selatan (Study site of HTI SBAWI in Ogan Komering Ilir - Sumatera Selatan)

\section{Metode Penelitian}

Keetch-Byram Drought Index (KBDI) merupakan indeks kekeringan yang dikembangkan untuk pengendalian kebakaran hutan di Florida, Amerika Serikat (Keecth \& Byram, 1968). Indeks ini mencerminkan kondisi kelembaban tanah, dimana semakin tinggi nilainya berarti tanah tersebut semakin kering. Nilai indeks berkisar pada angka 0 - 800 bila hujan diukur dalam satuan inchi, 0 - 203.2 dalam satuan SI (Crane, 1982 dalam Alexander, 1990) dan kisarannya menjadi 0 - 2000 bila hujan dalam satuan $\mathrm{mm}$ (Buchholz \& Weidemenn, 2000). Dikaitkan dengan potensi bahaya kebakaran nilai KBDI diklasifikasikan atas 4 level, yaitu potensi rendah 0 - 1000 (LOW), sedang 1000 - 1500 (MOD), tinggi $1500-1750(\mathrm{HGH})$ dan ekstrim 1750 - 2000 (EXT) (Buchholz \& Weidemenn, 2000).

Mengingat data yang digunakan lebih sedikit dan mudah dalam proses perhitungannya KBDI semakin banyak diaplikasikan (Dimitrakopoulos \& Bemmerzouk, 2003), terutama di negera berkembang yang pada umumnya mempunyai keterbatasan peralatan ukur cuaca. Dalam KBDI, data yang dibutuhkan hanya hujan dan suhu maksimum harian dan bila di lahan basah diperlukan data kedalaman muka air tanah.
Ketiga variabel ini dapat diukur manual setiap hari sebagaimana biasanya. Namun demikian, pengukuran menggunakan sensor dan alat penyimpan data (logger) jauh lebih praktis dan juga tidak terlalu mahal bila dilihat dari kualitas data yang dihasilkan.

Nilai KBDI dihitung berdasarkan persamaan berikut (Setiawan et al., 2009):

$Q^{t}=Q^{t-1}+Q^{t}-Q_{H}^{t}$

dimana, $Q$ adalah nilai KBDI, $Q_{T}$ adalah faktor kekeringan, $Q_{R}$ adalah faktor hujan, dan $Q_{H}$ adalah faktor air tanah, dan $t$ adalah waktu (hari). Faktor hujan dan faktor air tanah mengurangi nilai KBDI dan sebaliknya faktor suhu menambah nilai KBDI.

Faktor kekeringan dihitung sebagai berikut (Buchholz and Weidemenn, 2000; Setiawan et al., 2009).

$Q_{T}^{t}=\left[Q_{m x}-Q^{t h-1}\right] \times \frac{\left[a_{T} \exp \left(b_{T}{ }^{*} T_{m x}+d_{T}-c_{T}\right]\right.}{1+a_{R} \exp \left(-b_{R}{ }^{*} R_{\text {amn }}\right)} \times 10-3$

dimana, $Q_{m x}$ adalah nilai KBDI maksimum (dalam hal ini, 2000), $T_{m x}$ adalah suhu udara maksimum harian dan $R_{a n n}$ adalah curah hujan tahunan, dan $a_{T}, b_{T}, c_{T}$ dan $d_{T}$ adalah parameter suhu udara dan $a_{R}$ dan $b R$ adalah parameter hujan tahunan. 
Faktor hujan dihitung sebagai berikut (Buchholz \& Weidemenn, 2000).

$Q_{R}^{t}=R^{t}-5.1$

dimana, $R$ adalah hujan harian yang diperhitungkan bila melebihi $5,1 \mathrm{~mm} /$ hari.

Faktor air tanah dihitung sebagai berikut (Setiawan et al., 2009).

$\mathrm{Q}_{R}^{\mathrm{t}}=a_{H}-b_{H}^{*} \theta(h)^{t}$

dimana, $\theta$ adalah kadar air tanah volumterik, $h$ adalah jarak antara muka air tanah dan permukaan tanah, dan $a_{H}$ dan $b_{H}$ adalah parameter air tanah. Hubungan antara kadar air tanah dan muka air tanah didekati dengan persamaan retensi air tanah berikut (Genuchten, 1980).

$\theta(h)=\theta_{R}+\left(\theta_{\mathrm{S}}-\theta_{\mathrm{R}}\right) \cdot \mathrm{S}^{-1}$

$\mathrm{S}=\left\{1+\left|\frac{\mathrm{n}}{\alpha}\right|^{\mathrm{n}}\right\}^{\mathrm{m}}$

dimana $\theta_{\mathrm{S}}$ adalah kadar air tanah jenuh, $\theta_{R}$ kadar air tanah residual, $\mathrm{S}$ adalah derajat kejenuhan, serta $\alpha, n$ dan $m$ adalah parameter retensi air tanah. Tabel 1 menyajikan perkembangan model KBDI dilihat dari kebutuhan data dan parameter yang digunakan.

Tabel(Table) 1. Perkembangan parameter KBDI berdasarkan kebutuhan data (KBDI's parameter development following data necessity)

\begin{tabular}{|l|c|c|c|c|c|c|c|c|c|c|c|c|c|c|}
\hline & \multicolumn{3}{|c|}{$\begin{array}{c}\text { Suhu Maksimum } \\
\text { (Maximum temperature) }\end{array}$} & $\begin{array}{c}\text { Hujan Tahunan } \\
\text { (The Anmually } \\
\text { rain fall) }\end{array}$ & $\begin{array}{c}\text { Air Tanah } \\
\text { (Ground water) }\end{array}$ & \multicolumn{3}{|c|}{$\begin{array}{c}\text { Retensi air tanah } \\
\text { (Ground water retention) }\end{array}$} \\
\hline Parameter & $a_{T}$ & $b_{T}$ & $c_{T}$ & $d_{T}$ & $a_{R}$ & $b_{R}$ & $a_{H}$ & $b_{H}$ & $\theta_{S}$ & $\theta_{r}$ & $\alpha$ & $n$ & $m$ \\
\hline Keetch \& Byram (1968) & $\sqrt{ }$ & $\sqrt{ }$ & $\sqrt{ }$ & & $\sqrt{ }$ & $\sqrt{ }$ & & & & & & & \\
\hline Crane (1982) & $\sqrt{ }$ & $\sqrt{ }$ & $\sqrt{ }$ & $\sqrt{ }$ & $\sqrt{ }$ & $\sqrt{ }$ & & & & & & & \\
\hline Buchholz \& Weidemenn (2000) & $\sqrt{ }$ & $\sqrt{ }$ & $\sqrt{ }$ & $\sqrt{ }$ & $\sqrt{ }$ & $\sqrt{ }$ & & & & & & & \\
\hline Setiawan et al. (2009) & $\sqrt{ }$ & $\sqrt{ }$ & $\sqrt{ }$ & $\sqrt{ }$ & $\sqrt{ }$ & $\sqrt{ }$ & $\sqrt{ }$ & $\sqrt{ }$ & $\sqrt{ }$ & $\sqrt{ }$ & $\sqrt{ }$ & $\sqrt{ }$ & $\sqrt{ }$ \\
\hline
\end{tabular}

\section{Analisa Data}

Data hidrologi dan cuaca disusun dalam Ms. Excel 2003 berdasarkan bulan pengamatan. Indeks kekeringan KBDI $\left(Q^{t}\right)$ untuk lahan basah dihitung dengan Pers. (1) - (6). Dalam perhitungan awal, nilai parameter KBDI Buchholz and Weidemenn (2000) digunakan sebagai nilai default. Nilai parameter KBDI untuk lokasi SBAWI, OKI diperoleh dengan cara proses optimisasi paremeter dengan menggunakan Solver.

Proses optimasi dilakukan untuk memperoleh nilai $Q_{\mathrm{t}}$ yang memberikan beda nilai terkecil (Root Mean Squared Error, RMSE) dengan indeks kekeringan pengukuran $\left(Q_{\theta}\right)$. Nilai $Q_{\theta}$ mencerminkan kondisi kelembaban tanah aktual $(\theta)$ yang hubungannya dapat dinyatakan dengan Persamaan (7) (Setiawan et al., 2009).

$Q_{\theta}=\left(1-\frac{Q_{\theta}-Q_{R}}{Q_{S}-Q_{R}}\right) \cdot Q$

Nilai KBDI $Q_{\mathrm{t}}$ yang diperoleh perlu dikalibrasi dengan nilai $Q_{\theta}$ dengan cara mencari hubungan linear antara $Q_{\theta}$ dan $Q_{\mathrm{t}}$ sehingga diperoleh nilai intersepsi (a) dan slope (b) yang digunakan untuk menghitung KBDI kalibrasi, $Q_{k}$ (Persamaan 8).
$Q_{k}=a \cdot Q \mathrm{t}+b$

$Q_{k}$ merupakan nilai KBDI akhir yang digunakan sebagai indikator untuk melihat bahaya kebakaran hutan di lokasi.

\section{HASIL DAN PEMBAHASAN}

\section{A. Hasil}

Hasil pengamatan curah hujan harian di Stasiun pengamatan HQ Baung pada periode 1 April 2009 - 11 Mei 2010 diperoleh curah hujan yang tinggi. Total curah hujan selama 406 hari pengamatan yaitu sebesar $2.854 \mathrm{~mm}$ dengan hari hujan sebanyak 197 hari. Secara umum curah hujan tinggi terjadi pada musim penghujan yaitu periode bulan November - April mengikuti pola curah hujan monsunal di Indonesia. Pada bulanbulan tersebut curah hujan bulanan melebihi 200 $\mathrm{mm}$. Curah hujan tertinggi terjadi pada bulan April 2010 sebesar $384 \mathrm{~mm}$. Periode kering terjadi pada bulan Mei - Oktober 2009 dengan curah hujan bulanan terendah pada bulan September 2009 sebesar 22,6 mm.

Kisaran suhu udara maksimum di Stasiun HQ Baung selama periode pengamatan yaitu antara $26,6-34,9{ }^{\circ} \mathrm{C}$ dengan rata-rata Tmax 
sebesar $32,5^{\circ} \mathrm{C}$. Suhu udara maksimum tertinggi sebesar $34,9{ }^{\circ} \mathrm{C}$ terjadi pada 21 September 2009 dan terendah sebesar $26,6^{\circ} \mathrm{C}$ pada 8 Januari 2010.

KAT di Stasiun HQ Baung berfluktuasi pada kisaran $0,289 \mathrm{~m}^{3} / \mathrm{m}^{3}$ hingga $0,627 \mathrm{~m}^{3} / \mathrm{m}^{3}$. KAT tertinggi terjadi pada tanggal 9 April 2009 dan terendah pada tanggal 3 Oktober 2009. Pada bulan-bulan basah KAT cenderung mendekati KAT jenuh sedangkan pada bulan-bulan kering KAT mendekati level titik layu permanen. Bahkan, level KAT pernah di bawah titik layu permanen seperti KAT pada tanggal 1 - 4 Oktober 2009.

MAT di Stasiun HQ Baung berfluktuasi hingga kedalaman $1 \mathrm{~m}$. Secara umum MAT pada musim penghujan akan dekat permukaan tanah dan bahkan pada kondisi curah hujan yang tinggi menyebabkan genangan seperti yang terjadi pada tanggal 29 Desember 2009.

Perhitungan KBDI dimulai pada kadar air tanah maksimum terukur yaitu pada tanggal 9 April 2010. Pada tanggal tersebut kadar air tanah sebesar $0,627 \mathrm{~m}^{3} / \mathrm{m}^{3}$ atau setara dengan indeks kekeringan sebesar 43. Keetch \& Byram (1968) menyarankan penghitungan KBDI dapat dimulai pada awal musim semi dimana nilai KBDI sangat rendah. Penghitungan KBDI juga dapat dimulai pada periode hujan yang melimpah sebesar 150 -
$200 \mathrm{~mm}$ /minggu meskipun secara aktual KBDI tidak bernilai nol. Untuk perhitungan model, KBDI awal model $\left(Q_{t}\right)$ diberi angka 43 juga. Optimisasi dengan Solver menghasilkan nilai RMSE sebesar 16 dengan $\mathrm{R}^{2}$ sebesar 0,694 . Hasil optimisasi parameter model KBDI disajikan pada Tabel 2. Hasil optimasi memberikan nilai parameter baru untuk variable $Q_{H}$ dimana parameter $a_{H}$ dan $b_{H}$ secara berturutan bernilai 120 dan 0,216 .

Faktor muka air tanah $\left(Q_{H}\right)$ memberikan pengurangan terhadap KBDI hingga 102 angka setara dengan pengurangan maksimum KBDI karena faktor hujan. Semakin dekat muka air tanah dengan permukaan maka pengurangan nilai KBDI semakin besar. Hubungan antara faktor muka air tanah dengan kedalaman muka air tanah disajikan pada Gambar 2. Hasil penelitian juga menunjukkan pengurangan nilai KBDI tidak terjadi pada semua kedalaman muka air tanah. Penelitian ini mendapatkan kedalaman muka air tanah kritis yang memberikan pengurangan terhadap nilai KBDI yaitu pada kedalaman 0,659 m. Pada kedalaman ini muka air tanah masih berpengaruh terhadap kelembaban tanah lapisan atas. Hal ini sangat penting mengingat kelembaban tanah lapisan atas sangat penting dalam menjaga kelembaban bahan bakar di hutan.

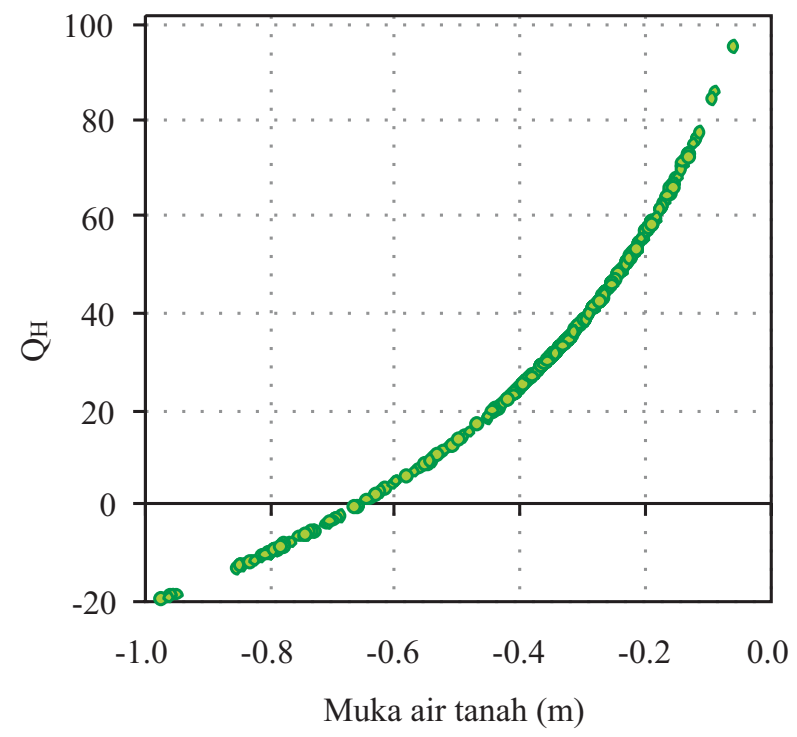

Gambar(Figure)2. Hubungan faktor muka air tanah dengan kedalaman muka air tanah (Relationship between water table factor and water table depth) 
Tabel(Table) 2. Perbandingan nilai parameter KBDI sebelum dan sesudah optimasi (KBDI's parameter value; before and after oprimization)

\begin{tabular}{|l|l|c|c|}
\hline Variabel & Parameter & $\begin{array}{c}\text { Buchholz \& Weidemenn } \\
\mathbf{( 2 0 0 0 )}\end{array}$ & Penelitian ini \\
\hline$Q$ & $Q_{\max }$ & 2000 & 2000 \\
\hline \multirow{3}{*}{$d Q$} & $a_{T}$ & 0,9680 & 1,1714 \\
& $b_{T}$ & 0,0875 & 0,0572 \\
& $c_{T}$ & 8,3000 & 8,2750 \\
& $d_{T}$ & 1,5520 & 1,7588 \\
& $a_{R}$ & 10,8800 & 10,8804 \\
& $b_{R}$ & 0,0017 & 0,0046 \\
$Q_{H}$ & $a_{H}$ & - & 120 \\
& $b_{H}$ & - & 0,2160 \\
\hline RMSE & & & 0,6940 \\
$\mathrm{R}^{2}$ & & & 0,884 \\
$Q_{k}$ & $a$ & & \\
\end{tabular}

Nilai KBDI meningkat secara alami dengan datangnya musim kemarau dan turun dengan datangnya musim penghujan (Gambar 3). Penghitungan KBDI dimulai pada tanggal 9 April 2010 dengan nilai indeks sebesar 43. Mengingat lokasi penelitian terletak di lintang ekuator, suhu udara maksimum harian selalu di atas $25^{\circ} \mathrm{C}$. Hal tersebut berdampak pada peningkatan nilai KBDI terjadi setiap hari. Jika ada hujan nilai indeks akan berkurang sesuai dengan besarnya hujan yang terjadi. Pengurangan indeks juga terjadi jika kedalaman muka air tanah di atas 0,659 m. Nilai KBDI mencapai maksimum 2000 yaitu pada tanggal 4 Oktober 2009 dimana kadar air tanah sebesar $0,299 \mathrm{~m}^{3} / \mathrm{m}^{3}$. Kadar air tanah ini berada dibawah titik layu permanen. Adanya hujan deras sebesar 45,6 mm pada hari berikutnya mampu mengurangi KBDI hingga turun menjadi 1892.

\section{CURAH HUJAN \& KBDI SUNGAI BAUNG, OKI-SUMSEL}

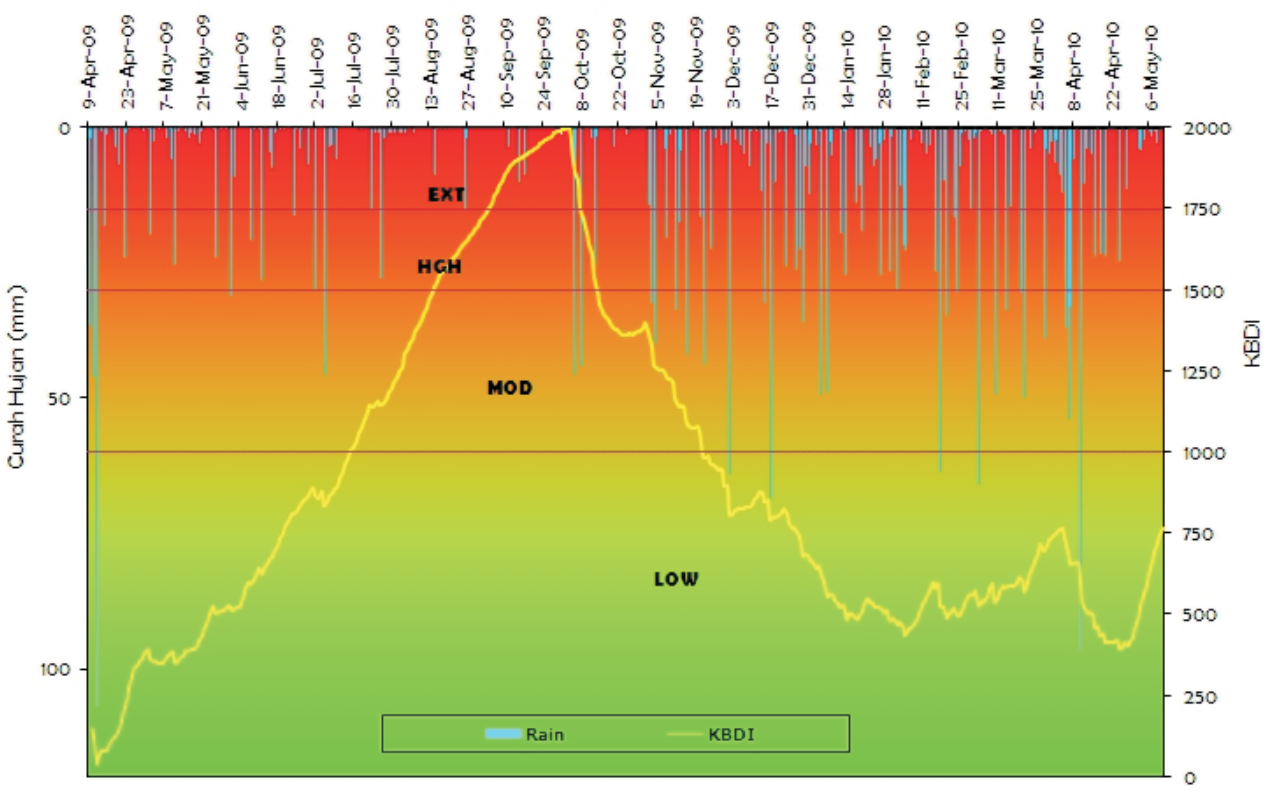

Gambar(Figure) 3. Dinamika harian KBDI di lokasi kajian (Dynamics of daily KBDI at the study site) 
Pengaruh curah hujan terhadap penurunan nilai KBDI pada bulan-bulan kering hanya bersifat sementara. Pada tanggal 2 Juli 2009, curah hujan sebesar $30 \mathrm{~mm}$ mampu menghambat laju peningkatan KBDI untuk mencapai kriteria bahaya kebakaran Sedang dengan penurunan indeks sebesar 23 angka. Kejadian hujan pada tanggal 5 Juli 2009 sebesar $46 \mathrm{~mm}$ juga menurunkan nilai KBDI. Setelah periode hujan tersebut, KBDI meningkat tajam ke level kriteria bahaya kebakaran yang lebih tinggi. Adanya hujan hanya mampu menahan laju peningkatan KBDI yang bersifat sementara seperti pada kejadian hujan tanggal 26 Juli 2010.

\section{B. Pembahasan}

Curah hujan sangat berpengaruh terhadap dinamika KAT dan MAT. Fluktuasi keduanya sangat dipengaruhi oleh dinamika curah hujan yang turun dan membasahi tanah. Pada musim penghujan seperti pada Bulan April, KAT mendekati level jenuh hingga mencapai KAT $0,627 \mathrm{~m}^{3} / \mathrm{m}^{3}$. KAT mulai berkurang dengan berakhirnya musim penghujan pada bulan Mei 2009. Bahkan KAT mencapai titik layu permanen pada tanggal 12 September 2009 sebesar 0,32 $\mathrm{m}^{3} / \mathrm{m}^{3}$. Selanjutnya KAT meningkat menjadi $0,335 \mathrm{~m}^{3} / \mathrm{m}^{3}$ pada tanggal 15 September 2009 dengan adanya hujan sebesar 10,2 mm. KAT kemudian mencapai titik terendah sebesar 0,289 $\mathrm{m}^{3} / \mathrm{m}^{3}$ pada tanggal 3 Oktober 2009. Hujan sebesar $2 \mathrm{~mm}$ (4 Oktober 2010) menyebabkan KAT naik menjadi $0,299 \mathrm{~m}^{3} / \mathrm{m}^{3}$. Hujan sebesar 45,6 mm (tanggal 5 Oktober 2009) menyebabkan KAT naik hingga $0,415 \mathrm{~m}^{3} / \mathrm{m}^{3}$ dan MAT naik dari $-0,744 \mathrm{~m}$ ke $-0,125 \mathrm{~m}$. Dengan dimulainya musim hujan, KAT selalu berada diatas $0,4 \mathrm{~m}^{3} / \mathrm{m}^{3}$, Sedangkan MAT meningkat sampai terjadi genangan seperti pada tanggal 31 Desember 2009 genangan mencapai $0,139 \mathrm{~m}$.

Kinerja model KBDI yang dikembangkan di lahan basah HTI SBAWI dapat dilihat dari kebakaran yang terjadi di sekitar Stasiun HQ Baung. Pada kriteria bahaya kebakaran Tinggi, di lokasi pernah terjadi kebakaran yaitu pada tanggal 19 Agustus 2009. Pada tanggal tersebut nilai KBDI sebesar 1589 . Kejadian kebakaran menunjukkan bahan bakar yang tersedia di hutan sudah cukup kering. Pada kondisi kering di Bulan September 2009, kebakaran hutan terjadi sebanyak lima kali yaitu pada tanggal: 5 September, 7 September, 11 September, 22 September, 29 September 2009. Selama bulan September 2009, kriteria bahaya kebakaran pada level Ekstrim. Hal ini menunjukkan model KBDI yang dikembangkan mampu menggambarkan potensi kebakaran di lokasi HTI SBAWI.

\section{KESIMPULAN}

1. KBDI yang dikembangkan dapat digunakan untuk deteksi bahaya kebakaran pada lahan basah.

2. Nilai KBDI yang mencerminkan bahaya kebakaran hutan dapat ditekan dengan mempertahankan kedalaman muka air tanah di atas $0,659 \mathrm{~m}$.

\section{UCAPAN TERIMA KASIH}

Penelitian ini didanai oleh Hibah Kompetensi DIREKTORAT PENDIDIKAN TINGGI DEPDIKNAS dengan No. Kontrak: 219/SP2H/ $\mathrm{PP} / \mathrm{DP} 2 \mathrm{M} / \mathrm{V} / 2009$. Ucapan terima kasih juga disampaikan untuk HTI Sebangun Bumi Andalas Wood Industries yang telah memberikan ijin dalam monitoring data cuaca dan hidrologi.

\section{DAFTAR PUSTAKA}

Ager A.A., M.A. Finney, B.K. Kerns and H. Maffei. 2007. Modeling Wildfire Risk to Northern Spotted Owl (Strix Occidentalis Caurina) Habitat in Central Oregon, USA. Forest Ecology and Management 246: 4556.

Alexander M.E. 1990. Computer Calculation of the Keetch-Byram Drought Index Programmers Beware! Fire Management Notes 51 (4): 23-25.

Buchholz G. and D. Weidemann. 2000. The Use of Simple Fire Danger Rating Systems as a Tool for Early Warning in Forestry. International Forest Fire News No. 23, 3236.

Burgan R.E. 1988. Revisions to the 1978 National Fire-Danger Rating System. Research Paper RP-SE-273. U.S. Department of Agriculture, Forest Service, Southeastern Forest Experiment Station, Asheville, NC, 39 p.

Chan D.W., J.T. Paul and A. Dozier. 2004. Keetch-Byram Drought Index: Can It Help 
Predict Wildland Fires? Fire Management Today 64(2): 39 - 42.

Cooke W., V. Anantharaj, C. Wax, J. Choi, K. Grala, M. Jolly, G.P. Dixon, J. Dyer, D.L. Evans and G.B. Goodrich. 2007. Integrating Climatic and Fuels Information into National Fire Risk Decision Support Tools. USDA Forest Service Proceedings RMRS-P-46CD. Page 555 - 569.

Crane W.J.B. 1982. Computing Grassland and Forest Fire Behavior, Relative Humidity and Drought Index by Pocket Calculator. Australian Forestry 45(2): 89-97.

Chuvieco E., I. Aguado, M. Yebra, H. Nieto, J. Salas, M.P. Martín, L. Vilar, J. Martínez, S. Martín, P. Ibarra, J. de la Riva, J. Baeza, F. Rodrígues, J.R. Molina, M.A. Herrera, R. Zamora. 2009. Development of a Framework for Fire Risk Assessment Using Remote Sensing and Geographic Information System Technologies. Ecol. Model. (in press), doi:10.1016/j. ecolmodel.2008.11.017.

Dimitrakopoulos A.P. and A.M. Bemmerzouk. 2003. Predicting Live Herbaceous Moisturecontent from a Seasonal Drought Index. Int J Biometeorol, 47:73-79. DOI 10.1007/s00484-002-0151-1.

Genuchten, M.Th. 1980. A Closed-Form Equation for Predicting the Hydraulic Conductivity of Unsaturated Soils. Soil Sci. Soc. Am. J. 44: 892-898.

Gill A.M. and S.L. Stephens. 2009. Scientific and Social Challenges for the Management of Fire-Prone Wildland-Urban Interfaces. Environ. Res. Lett. 4 (2009) 034014 (10pp). doi:10.1088/1748-9326/4/3/ 034014.

Johnstone J.F. and F.S. Chapin III. 2006. Effects of Soil Burn Severity on Post-Fire Tree Recruitment in Boreal Forest. Ecosystems 9: 14-31. DOI: 10.1007/s10021-0040042-x.

Keetch J.J. and G.M. Byram. 1968. A Drought Index for Forest Fire Control. USDA Forest Service Reseearch Paper SE-38.

Liu Y., J. Stanturf and S. Goodrick. 2010. Trends in Global Wildfire Potential in a Changing Climate. Forest Ecology and Management 259: 685-697.
Murdiyarso D., M. Widodo and D. Suyamto. 2002. Fire Risks in Forest Carbon Projects in Indonesia. Science in China. Vol. 45 Supp.

Page S.E., F. Siegert, J.O. Rieley, H-D. V. Boehm, A. Jaya and S. Limin. 2002. The Amount of Carbon Released from Peat and Forest Fires in Indonesia during 1997. Nature 420:61-65.

Reardon J., G. Curcio and R. Bartlette. 2009. Soil moisture dynamics and Smoldering Combustion Limits of Pocosin Soils in North Carolina, USA. Int. J.Wildland Fire 18, 326-335.

Setiawan B.I., M. Taufik, S. Afianto, Soewarso, J. Ginting and A. Harisman. 2009. Makalah Seminar Internasional: Achieving Resilient Agriculture to Climate Change through the Development of Climate based Management Scheme. Bogor, 17-19 November 2009. Penyelenggara: PERHIMPI.

Snyder R.L., D. Spano, P. Duce, D. Baldocchi, L. $\mathrm{Xu}$ and K.T. Paw U. 2006. A Fuel Dryness Index for Grassland Fire-Danger Assessment. Agricultural and Forest Meteorology 139 (2006) 1-11.

Sparks J.C., R.E. Masters, D.M. Engle and G.A. Bukenhofer. 2002. Season of Burn Influences Fire Behavior and Fuel Consumption in Restored Shortleaf PineGrassland Communities. Restoration Ecology Vol. 10 No. 4, pp. 714-722.

Stocks BJ, BD Lawson, ME Alexander, CE Van Wagner and RS McAlpine, TJ Lynham, and DE Dube. 1989. The Canadian Forest Fire Danger Rating System: An Overview. For. Chron. 65: 450 -457.

van der Werf G. R., J. Dempewolf, S. N. Trigg, J. T. Randerson, P. S. Kasibhatla, L. Giglio, D. Murdiyarso, W. Peters, D. C. Morton, G. J. Collatz, A. J. Dolman and R. S. DeFries. 2008. Climate Regulation of Fire Emissions and Deforestation in Equatorial Asia. PNAS 105 (51): 20350-20355. www.pnas.org/cgi/doi/10.1073/pnas.0803 375105.

Wallenius T.H., S. Lilja and T. Kuuluvainen. 2007. Fire History and Tree Species Composition in Managed Picea abies Stands in Southern Finland: Implications for Restoration. Forest Ecology and Management 250: 89-95. 
Weidemann G., G.Buchholz, Redhahari and A.A.Hoffmann (1998). Fire Danger System for East Kalimatan Province, Indonesia (in Indonesian).
Wybo J.L., F. Guraniéri and B. Richard. 1995. Forest Fire Danger Assessment Methods and Decision Support. Safety Science 20: $61-70$. 